\title{
FACTORS IN DETERMINING THE PREFERENCE OF FAIR VALUE METHOD OF INVESTMENT PROPERTY
}

\author{
Yennisa \\ Setya Juwiyato* \\ Dekeng Setyo Budiarto \\ Universitas PGRI Yogyakarta, Jln. PGRI I Sonosewu No. 117, Yogyakarta \\ "yennisa.icha@upy.ac.id
}

\author{
A R T I C L E I N F O \\ Article history: \\ Received October 24, 2019 \\ Revised May 4, 2020 \\ Accepted May 7, 2020
}

Key words:

Fair Value Method, Investment

Property, Financial Accounting

Standard

DOI:

https://doi.org/10.33508/jako.v12i2.2210

\begin{abstract}
A B S T R A C T
Financial Accounting Standard Statement in Indonesia is adopted from the IFRS by the IASB. IFRS applies those standards regarding the assessment of investment property as regulated in PSAK number 13. This research aims to determine the effect of leverage, firm size, asymmetry information, the difference in fair value gains, and share ownership on the selection of fair value investment property methods. This research is quantitative research with purposive sampling technique. The research was conducted on 69 companies listed on the Indonesia Stock Exchange in 2014-2017 with a total of 276 samples. The data analysis technique in this research used logistic regression analysis. The results indicate that firm size and asymmetry information influence the selection of the fair value method of investment property. The leverage, the difference in fair value profits, and share ownership do not affect. Based on the results of the research, there are still many firms that does not apply the fair value method because they prefer a more conservative accounting method. Additional costs regard to revaluation is one of the considerable factors why the firm resist to use the fair value method.
\end{abstract}

\begin{abstract}
A B S T R A K
Pernyataan Standar Akuntansi Keuangan di Indonesia diadopsi dari IFRS oleh IASB. IFRS menerapkan standar-standar tersebut mengenai penilaian properti investasi sebagaimana diatur dalam PSAK nomor 13. Penelitian ini bertujuan untuk mengetahui pengaruh leverage, ukuran perusahaan, informasi asimetri, perbedaan dalam perolehan nilai wajar, dan kepemilikan saham pada pemilihan properti investasi nilai wajar metode. Penelitian ini adalah penelitian kuantitatif dengan teknik purposive sampling. Penelitian ini dilakukan pada 69 perusahaan yang terdaftar di Bursa Efek Indonesia pada 2014-2017 dengan total 276 sampel. Teknik analisis data dalam penelitian ini menggunakan analisis regresi logistik. Hasil penelitian menunjukkan bahwa ukuran perusahaan dan informasi asimetri mempengaruhi pemilihan metode nilai wajar properti investasi. Leverage, perbedaan laba nilai wajar, dan kepemilikan saham tidak berpengaruh. Berdasarkan hasil penelitian, masih banyak perusahaan yang tidak menerapkan metode nilai wajar karena mereka lebih memilih metode akuntansi yang lebih konservatif. Biaya tambahan yang berkaitan dengan revaluasi adalah salah satu faktor penting mengapa perusahaan menolak untuk menggunakan metode nilai wajar.
\end{abstract}

\section{INTRODUCTION}

Publicly traded companies mandated to submit financial statement. Financial statement is one of sourcing information to stakeholders (Feronike and Budisantoso, 2017). The preparation of financial statement needs a guideline or standard to deliver a high quality of information to the users. IAI is mandated to regulate and establish the standard of financial statement in Indonesia SAK. SAK is a guideline to prepare financial statement in Indonesia (Sasongko and Marhamah, 2018).

SAK in Indonesia is adopted from IFRS that mandated from IASB (Umbara, Oemar, and Pranaditya, 2017). One of the implementations from IFRS is the preference of the valuation in investment property stated in PSAK no 13 (IAI, 2015) valuation of investment property consists of two 
methods; cost model and fair value. The implementation of fair value provides more relevant information in decision making. Fair value method tends to change (increasing or decreasing) the valuation of investment property (Sasongko and Marhamah, 2018). Management needs to focus on choosing the valuation method with the percentage of liability consideration.

Entity use percentage of liability to indicate the ability to pay long term liability. Entity has to survive in terms to pay debt to avoid the liquidation. Management tends to prefer cost method to value investment property in a high percentage of liability condition (Farahmita and Siregar, 2014). Cost method preference tends to cause fluctuation in earning or changing the value of investment property.

Firm size indicates the characteristic of financial. Firm size is the comparison in high or low in an object (Dewi, Zusmawati, and Lova, 2018). The bigger of publicly traded company means they tend to choose fair value in their investment property (Pratiwi and Tahar, 2017). Asymmetry information is the condition when management has an access in the firm than other parties/outsiders (Aristiani, Suharto and Sari, 2017). Management with high asymmetry information more considers choosing the best method for the firm. Management prefers to implement the revaluation model regarding to information that provides from outside (appraisal). Appraisal tends to give more reliable information than management.

IAI (2015) in PSAK no. 68 explains that fair value is the price in selling an asset in arms-length transaction at the measurement date. Gain or loss from fair value recognizes as an addition or reduction from the income statement of profit or loss and other comprehensive income. Entity revaluates the investment property to ensure that the carrying amount is equal to fair value. Investment property that being revaluated may increase or decrease the value of an asset. Gain in a revaluation of an asset not included in comprehensive income but recognize in the statement of profit or loss as a revenue. Gain in revaluation assets derived from fair value method as a measurement of an asset (Muller, Riedl dan Sellhorn, 2008).

Publicly traded company is the composition held by public and management. Public require high quality of information that disclose corporate action including the method to value an asset. Fair value method shows the great portion of an asset with the proper market value at the valuation date (Muller, dkk., 2008). There are inconsistent evi- dence that show asymmetry information impact on preferences of fair value method in investment property.

\section{LITERATURE REVIEW AND HYPOTHESIS DEVELOPMENT}

Literature Review

Agency Theory

Agency Theory is the relationship between the principal mandated an agent to provide service (Jensen and Meckling, 1976). Agent has the responsibility to manage the entity. In publicly traded company we conclude that stockholder act as a principal and management as an agent who runs the company. Management responsible to plan, execute, manage, control, and report the going concern of entity to the stockholder. The moral issue arises from management who tend to maximize their own wealth against the interest of stockholder.

\section{Fair Value}

PSAK no 68 (IAI, 2015) states that fair value is the price that would be received to sell an asset or paid to transfer a liability between market participants at fair value or current market price at the date of measurement. When valuing at fair value, management considers asset or liability characteristic. Characteristic an asset is the condition, location, limit of an asset when management decides to sell or use it. Fair value measurement assumes asset or liability that been exchanged in arm's length transaction between market participant when selling or transfering liability at the date of measurement in current market condition.

\section{The Preference of Valuation at Investment Property}

PSAK no 13 (IAI, 2015) state investment property consisting of land and building that owned by the entity through financial lease and available to rent or for capital appreciation or both. Investment property did not use in terms of production, goods acquisition, service, and inventory. Property is classified as an investment property if it qualifies the requirement in terms of usefulness and type of ownership. Investment property not in purpose for internal use or rent to external through financial lease. Investment property measurement consists of two methods; fair value and cost method. Entity prefers to choose fair value method tends to consider current market value at the reporting date. Fair value measurement of investment property based on recent price at active market. If there is no recent price, the entity determines fair value with 
other considerable information (Kadir, 2016).

\section{Debt Ratio}

Entity external sourcing capital derives from third party; short and long term loan. Debt ratio shows the ability of an entity to cover all the liabilities to third party. Debt ratio is the ability of an entity financial leverage in terms of percentage total debt to total asset. This is one of the ways of an entity to keep going concerned in doing business.

\section{Firm Size}

Firm size is the comparison of entity big or small business. Total asset, sales, market capitalization indicate the firm size. Big firm size has more asset, sales, and market capitalization than the small firm (Setiyono and Amanah, 2016). Many research prefers using total asset as a benchmark to firm size because its more stable than market price and sales. Firm size is one of the indicators in valuing the condition of the firm itself. Big or small firms may vary from total employee, total asset, total sales in one period of time and total outstanding shares (Santioso and Chandra, 2012).

\section{Asymmetry Information}

Asymmetry information is the difference between information held by agent and the principal. Agent has more information than principal. Agent has detail information regarding condition of the firm. Agent tend not to inform detailed conditions about entity to the public. Agent keeps the information until the right timing to inform to public (Wiryadi and Sebrina, 2013).

Investor will be looking for detail information before doing the investment decision. They buy securities/stock after they reveal the detail condition of the firm for a better investment decision. Asymmetry information may cause serious problems to management if it impacted investor in terms of loss (Manurung, 2013).

\section{Revaluation Surplus}

PSAK no 16 (IAI, 2015) state that fixed asset is tangible asset owned by an entity for production and acquisition of goods and services. It may earn rentals to other parties, administrative purposes, and expected has more than 1 year of useful lives. Fixed asset in the same qualification measure at cost. Management has to choose between cost model or the revaluation model after the initial recognition of an asset. Management consistently applies measurement model in one class of asset. Cost model recognizes asset at cost after reducing with accumulated depreciation and impairment of accumulated value of asset. Revaluation model use fair value to measure fixed asset after reducing with accumulated depreciation and impairment of accumulated value of asset at the revaluation date.

Management should conduct revaluation regularly after initiate to choose revaluation model. This means to ensure carrying amount not different with fair value at the balance sheet date. Surplus in carrying amount of asset after revaluation should be credited to revaluation surplus. In the other way if the carrying asset decrease after revaluation should be recognized as an expense.

\section{Stock Ownership}

Ownership structure of the stock consist of management and institutional ownership. Percentage of stock owned by institutional investor refers to the term of institutional ownership and percentage of stockholders from management refers to terms of management ownership (Apriada and Suardikha, 2013). Stock ownership determines from stock percentage owned by internal and external parties. Percentage of stock ownership determine ownership in the firm in minimum level 5\% from total capital in the firm.

\section{Hypotheses Development}

Management prefers to choose conservative accounting method because providing more assurance to the creditor. They assume that cost method more conservative than fair value method. Total debt ratio will impact the managerial decision in using fair value method. Based on the explanation above:

H1: Debt ratio affects to the preference of fair value method of investment property

Total asset one of the indicators to firm size. The bigger firm size, the smaller possibility management choose fair value method to measure investment property (Ishak, Tahir, Ibrahim and Wahab, 2012). Previous research shows that entity size impact to management consideration in using fair value method (Pratiwi and Tahar, 2017).

H2: Firm size affects to preference of fair value method of investment property

Asymmetry information occurs when there are differences between management (agent) and investor (principal) (Wiryadi and Sebrina, 2013). Asymmetry information affects to management preference of fair value method of investment property. The higher asymmetry information, the 
higher preference of fair value method of investment property (Farahmita and Siregar, 2014).

H3: Asymmetry information affects to preference of fair value method of investment property

Revaluation surplus in investment property occurs when there are differences between current market price and carrying amount. Revaluation surplus of fair value affects to preference of fair value method of investment property (Muller et al., 2008). Gain or loss from revaluation of investment property affects managerial decision in using fair value.

H4: Revaluation surplus affects preference of fair value method of investment property.

Stock ownership is percentage of stock owned by management and external parties (Apriada and Suardikha, 2013). Stock owned by public encourages management in determining fair value model regarding investment property measurement of an entity. Total stock owned by public affects preference of fair value method of investment property (Muller dkk., 2008).

H5: stock ownership affects preference of fair value method of investment property.

\section{Research Framework}

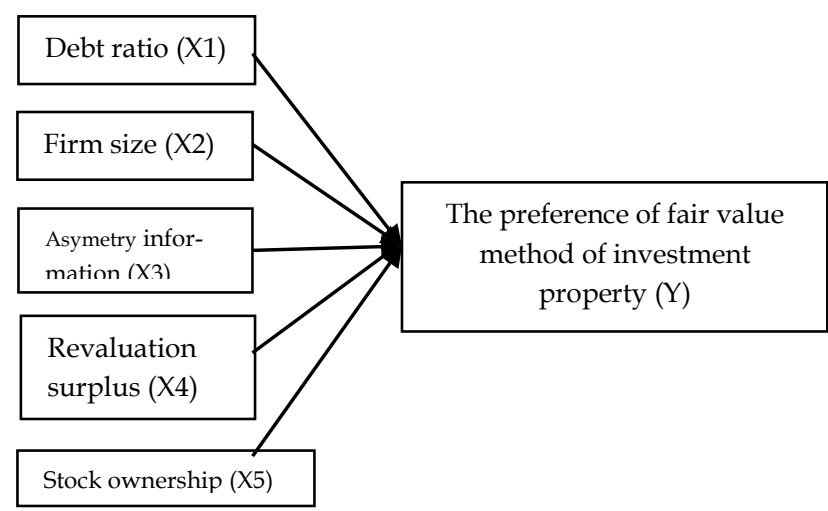

Picture 1. Research Framework

\section{METHODOLOGY}

\section{Population and Research Sampling}

Population in this research are all listed company in IDX from 2014-2017. Listed company in IDX have to submit financial statement and annual report regularly so all the financial information and management policies regarding investment property fairly and completely stated. Sampling method are using purposive sampling with these criteria below:

1. Listed company in IDX from 2014-2017

2. Company issue Annual Report and Financial Statement consistently from 2014-2017
3. Company own investment property from 20142017

4. Company disclose accounting method to value investment property

5. Financial statement stated financial statement in IDR currency respectively from 2014-2017

\section{Data Collection Technique}

Data collection technique used in this research are documentation techniques with collecting and applying available data as a source of information. Type data use is secondary data. Research data derived from Annual Report and Financial Statement issued from 2014-2017. Data derived from official website IDX (www.idx.co.id) and company official website.

\section{Variable Identification and Variable Definition}

Fair value of investment property is the price in active market. The preference of fair value model of investment property in this research is using dummy variable. If company use fair value $=1$, but if company use cost model $=0$ (Pratiwi and Tahar, 2017). Leverage or debt ratio is the ability of company to pay total liabilities (Santioso and Chandra, 2012). Debt ratio measure by total debt to total assets ratio are total debt ratio divided total asset in the year end (Farahmita and Siregar, 2014).

Firm size is the comparison between big and small companies with several factor considerations; total assets, total sales in a period of time, total outstanding stock (Setiyono and Amanah, 2016). Firm size in this research computes by natural algorithm from year end balance of company total asset (Pratiwi and Tahar, 2017).

Asymmetry information in this research compute by market to book value (MTB) is the comparison between stock market value with company book value. Market value derived from multiplying outstanding stock with stock market price. Company book value is the value from total equity reduce with preferred stock (Farahmita and Siregar, 2014).

Revaluation asset can cause increasing or decreasing the value of an asset when increasing carrying amount of asset management credited to revaluation surplus (Martani, Siregar, Wardani, Farahmita dan Tanujaya, 2012). Revaluation surplus derived from log natural from revaluation surplus balance from investment property (Farahmita and Siregar, 2014).

Stock ownership is the percentage of stock owned by management and institutional (Apriada and Suardikha, 2013). Stock ownership uses variable dummy if stock owned by public more than 
$50 \%=1$ and if less than $50 \%=0$ (Pratiwi and Tahar, 2017).

\section{Data Analysis Method}

This research use logistic regression because dependent and independent variable are combination between metric and non metric.

Regression equation:

$$
\operatorname{Ln}\left(\frac{p}{1-p}\right)=\propto+\beta 1 X 1+\beta 2 X 2+\beta 3 X 3+\beta 4 X 4+\beta 5 X 5
$$

Explanation:

$\begin{array}{ll}\operatorname{Ln}\left(\frac{p}{1-p}\right) & \begin{array}{l}\text { : preference of fair value methos of } \\ \text { investment property: } \\ \text { : constanta }\end{array} \\ \text { a } & \text { : debt Ratio } \\ \text { X1 } & \text { : firm size } \\ \text { X2 } & \text { : asymetry informastion } \\ \text { X3 } & \text { : revaluation surplus } \\ \text { X4 } & \text { : stock ownership } \\ \text { X5 } & \text { : variable coeff } 1,2,3,4,5\end{array}$

\section{RESULTS AND DISCUSSION}

\section{Deskriptive Statistic}

Table 1. Deskriptive Test Result

\begin{tabular}{|c|l|c|c|c|c|}
\hline No & \multicolumn{1}{|c|}{ Variable } & Mean & Min & Max & $\begin{array}{c}\text { Std. } \\
\text { Dev. }\end{array}$ \\
\hline 1 & $\begin{array}{l}\text { Preference of } \\
\text { fair value } \\
\text { meth of in- } \\
\text { vestment } \\
\text { property (Y) }\end{array}$ & 0,18 & 0 & 1 & 0,39 \\
\hline 2 & $\begin{array}{l}\text { Debt ratio } \\
(\text { X1) }\end{array}$ & 0,45 & 0,03 & 0,93 & 0,21 \\
\hline 3 & $\begin{array}{l}\text { Firm size } \\
\text { (X2) }\end{array}$ & 29,19 & 25.30 & 33,32 & 1,57 \\
\hline 4 & $\begin{array}{l}\text { Asymetry } \\
\text { information } \\
\text { (X3) }\end{array}$ & 1,97 & 0,04 & 22,29 & 3,18 \\
\hline 5 & $\begin{array}{l}\text { Revaluation } \\
\text { surplus (X4) }\end{array}$ & 3,69 & 0 & 28,19 & 8,76 \\
\hline 6 & $\begin{array}{l}\text { Stock owned } \\
\text { by public } \\
\text { (X5) }\end{array}$ & 0,15 & 0 & 1 & 0,36 \\
\hline
\end{tabular}

Source: Data processed

The dependent variable of this research is the preference of the fair value method of investment property, companies can choose between the fair value method or the cost method. The lowest value is 0 , it means the company uses the cost method. The highest value is 1 , it means that the company uses the fair value method. The average value is 0.18 , which means that the average value of the preference fair value method of investment properties for 69 companies in 2014-2017 is 18\%. Standard deviation of 0.39 shows the average value is smaller than the standard deviation.

The first independent variable is debt ration calculated by comparing total debt with total assets. The lowest value of the debt level is 0.03 , while the highest value is 0.93 . The average value of 69 companies in 2014-2017 was 0.45 and the standard deviation was 0.21 . The second independent variable is firm size, this variable is measured using natural logarithms of total assets. The size of the company has a minimum value of 25.30 and a maximum value of 33.32. The average value shows a value of 29.19 or greater than the standard deviation value of only 1.57 . The third independent variable is asymmetric information, this variable is measured using the market to book value ratio. The asymmetry information in the table above has a maximum value of 22.29 and a minimum value of 0.04 . The standard deviation of this variable shows at 3.18 while the average value is 1.96 . Smaller mean values indicate that the standard error on this variable is high.

The fourth independent variable is revaluation surplus. Variables are proxied using natural logarithms of revaluation surplus of investment properties. The minimum value is 0 and the maximum value is 28.19 . The average value of this variable is 3.69 and the standard deviation is 8.76. The last independent variable is public stock ownership, a company can have a public share greater than $50 \%$ or public share ownership of less than $50 \%$. The lowest value is 0 , meaning the company has a public share of less than $50 \%$. The highest value is 1 , meaning the company has more than $50 \%$ public shares. The average value is 0.15 and the standard deviation is 0.36 .

\section{Testing for significance}

Based on the $\mathrm{F}$ test, the Chi-square value of 209.016 showed a significance level of $0.000<0.05$. This test shows that $\mathrm{H} 0$ is accepted and it can be concluded that the hypothesized model is fits with the data.

\section{Hosmer and Lemeshow of Fit Test}

The results of the Hosmer and Lemeshow of Fit Test with the probability of significance indicate the number 0.335 . The significance value obtained is greater than 0.05 so $\mathrm{H} 0$ is accepted. This means 
that the regression model is feasible to be used in further analysis because there is no big difference between the predicted classification and the observed classification.

\section{Matrix test}

The classification matrix describes the results of predictions for companies using the cost method of 225, while the results of observations of companies using the cost method are also 225. This results in a classification accuracy of $100 \%$. The prediction results for companies that use the fair value method are 51, while the results of observations of companies that use the fair value method are 43 with a classification accuracy of $84.3 \%$. Based on the explanation above, it can be concluded that the predictive power of the regression model is $97.1 \%$.

\section{Hypotheses test}

Logistic Regression Test

Logistic equation:

$$
\begin{gathered}
\operatorname{Ln}\left(\frac{p}{1-p}\right)=-33,97-3,87 X 1+1,14 X 2-1,36 X 3 \\
+1,63 X 4-18,73 X 5
\end{gathered}
$$

Explanation:

$\operatorname{Ln}\left(\frac{p}{1-p}\right) \quad$ : Prefere nce of fair value method of investment property

$\mathrm{X} 1 \quad$ : Debt ratio

X2 : Firm size

X3 : Asymetry information

X4 : Revaluation surplus

X5 : Stock owned by public

Result logistic regression test

Table 2. Result Logistic Regression Test

\begin{tabular}{|c|l|c|c|c|c|}
\hline No & \multicolumn{1}{|c|}{ Variable } & B & Wald & Sig. & $\begin{array}{c}\text { Exp } \\
\text { (B) }\end{array}$ \\
\hline 1 & $\begin{array}{l}\text { Preference } \\
\text { of fair value } \\
\text { meth of in- } \\
\text { vestment } \\
\text { property (Y) }\end{array}$ & $-3,87$ & 3,11 & 0,078 & 0,02 \\
\hline 2 & $\begin{array}{l}\text { Debt ratio } \\
\text { (X1) }\end{array}$ & 1,14 & 9,29 & 0,002 & 3,14 \\
\hline 3 & $\begin{array}{l}\text { Firm size } \\
\text { (X2) }\end{array}$ & $-1,36$ & 4,20 & 0,040 & 0,25 \\
\hline 4 & $\begin{array}{l}\text { Asymetry } \\
\text { information } \\
\text { (X3) }\end{array}$ & 1,63 & 0 & 0,989 & 5,13 \\
\hline 5 & $\begin{array}{l}\text { Revaluation } \\
\text { surplus (X4) }\end{array}$ & $-18,73$ & 0 & 0,997 & 0 \\
\hline 6 & Constant & $-33,97$ & 9,89 & 0,002 & 0 \\
\hline
\end{tabular}

Source: Data processed
The results of the test show debt ratio have Wald value with a significance of 0.078 (greater than 0.005). With this value, the first hypothesis (H1) is rejected. The results of calculations partially state the level of debt has no effect on the possibility of management choosing a fair value for investment property. The debt level has an odds ratio of 0.02 , meaning that the debt level influences companies to use the fair value method 0.02 times compared to choosing the cost method.

The second hypothesis $(\mathrm{H} 2)$ is accepted because Wald's value is 0.002 or smaller than 0.05 . These results indicate that firm size influences the choice of the fair value method of investment property. The size of the company has an odds ratio of 3.14, meaning that the size of the company influences the company to use the fair value method 3.14 times compared to choosing the cost method.

This partial hypothesis shows testing of asymmetric information variables. The significance value of this variable is 0.040 or smaller than the significance level of 0.05 . So the third hypothesis (H3) in this study was accepted. Asymmetric information affects the choice of the fair value method of investment property. Asymmetric information has an odds ratio of 0.25 , meaning that asymmetric information influences companies to use the fair value method 0.25 times compared to choosing the cost method.

The results of partially test the revaluation surplus to the dependent variable is 0.989 (greater than 0.05). With this value, the fourth hypothesis $(\mathrm{H} 4)$ is rejected, so that the difference revaluation surplus does not affect the dependent variable. Based on the results of the test the revaluation surplus has an odds ratio of 5.13 , meaning that the difference in fair value gains affects companies to use the fair value method 5.13 times compared to choosing the cost method.

Based on the results of test on public share ownership has a Wald value with a significance of 0.997 (greater than 0.005). With this value, the last hypothesis (H5) is rejected. The results of a partial calculation, public ownership does not affect the selection of the method of fair value of investment property. Public share ownership has an odds ratio of 0 , meaning that public share ownership influences companies to use the fair value method 0 times compared to choosing the cost method.

\section{Discussion}

Based on the results of regression testing, the level of corporate liability has no effect on the 
preference of the fair value method for investment property. The results of this study support previous research, according to Pratiwi and Tahar (2017) the level of debt owned by an entity has no influence on the use of a fair value model for investment properties. Companies prefer to use the cost method because it is considered more conservative. This study is in line with the research of Taplin, Yuan, and Brown (2014), whether or not the issuer's level of debt will not affect management's decision to use the fair value model. The higher level of debt held does not affect management's decision to choose the fair value method as a measure of investment property.

Firm size influences the preference of fair value method for investment property. This study supports research conducted previously, according to Pratiwi and Tahar (2017) the higher the size of a company, the greater the consideration for choosing fair value for assets owned, especially investment property. Based on the research results of Ishak dkk. (2012) stated that high size companies have a low probability of choosing fair value as a method for investment property.

Asymmetric information on the company affects the consideration in choosing the fair value method. Companies that have investment properties will choose to use the fair value method by considering asymmetric information proxied through market to book value. These results support research conducted by Farahmita and Siregar (2014) also Quagli and Avallone (2010), companies with high asymmetric information will influence management decisions regarding the fair value model for assets (investment properties).

The Revaluation surplus does not affect the selection of the fair value method for investment property. Investment property in companies that use the fair value model is not affected by the size of the increase or decrease in fair value. Research conducted by Farahmita and Siregar (2014) also Pratiwi and Tahar (2017) states the revaluation surplus does not have an effect on management's decision to use the fair value method. The greater the fair value gain after revaluation does not have an effect on the likelihood that management chooses the fair value method for recording investment properties owned. So it can be concluded that the results of the study are in accordance with previous studies.

Stock ownership does not affect the choice of fair value for investment properties. Companies with a level of public ownership of more than $50 \%$ do not have an effect on the possibility of choosing fair value as the method to be used. This study supports research conducted by Pratiwi and Tahar (2017) stating that company shares owned by the wider community do not have an effect on management actions to use a fair value model on assets owned (investment properties).

\section{CONCLUSION}

Based on the results of data analysis, it can be concluded that the debt ratio does not affect the choice of the fair value method of investment property, thus the hypothesis is not accepted. Companies with high debt levels use more cost methods to measure investment property. Firm size influences the choice of the fair value method of investment property, so the hypothesis is accepted. Companies with large sizes will usually choose the right accounting method and in accordance with applicable standards or regulations. Asymmetric information affects the choice of the fair value method of investment property, thus the hypothesis is rejected. The higher asymmetric information does not encourage companies to use the fair value model. Revaluation surplus does not affect the choice of the fair value method of investment property, so the hypothesis is rejected. The revaluation surplus in investment property (high fair value) does not cause companies to use the fair value method to measure their assets. The ownership of public stock does not affect the choice of the fair value method of investment property, thus the hypothesis is not accepted. Consideration on the use of the asset's fair value method (investment property) is not influenced by the percentage of share ownership by the public. Based on the results of the study there are still many companies that do not apply the fair value method because companies prefer more conservative accounting methods and the additional costs when changing methods or when revaluing.

Based on the above results, further research is expected to add other variables that are thought to influence the choice of the fair value method of investment property, one of which is earnings management. Further research can add to the vulnerability of research time, by entering 2018 . Further research can expand the object of research, not only in Indonesia but across countries. 


\section{REFFERENCES}

Apriada, K., dan Suardikha, M. S. (2013). Pengaruh Struktur Kepemilikan Saham, Struktur Modal dan Profitabilitas pada Nilai Perusahaan. E-Jurnal Ekonomi dan Bisnis Universitas Udayana, 5(2), 201-218.

Aristiani, O. F., Suharto, S., dan Sari, G. P. (2017). Pengaruh Prudence Terhadap Asimetri Informasi Dengan Kualitas Laba Sebagai Variabel Moderasi Studi Empiris Pada Indexs Lq45 Yang Terdaftar Di BEI. Akuisisi: Jurnal Akuntansi, 13(2), 62-82.

Dewi, A. S., Zusmawati, Z., \& Lova, N. H. (2018). Analisis Kinerja Keuangan dan Ukuran Perusahaan terhadap Harga Saham Perusahaan dalam Indeks LQ45 di BEI dengan Regresi Data Panel. Jurnal Pundi, 2(2), 119-134.

Farahmita, A., dan Siregar, S. V. (2014). Faktorfaktor yang Mempengaruhi Kemungkinan Perusahaan Memilih Metode Nilai Wajar untuk Properti Investasi. Prosiding. Simposium Nasional Akuntansi XVII: Mataram.

Feronike, N. I., dan Budisantoso, T. (2017). Pengaruh Ukuran KAP, Kondisi Keuangan Perusahaan, Opini Audit Tahun Sebelumnya, Pertumbuhan Perusahaan Terhadap Opini Audit Going Concern. Modus Journals, 27(1), 1-12.

Ikatan Akuntan Indonesia. (2015). Standar Akuntansi Keuangan. Jakarta: IAI.

Ishak, H. S., Tahir, H. H. M., Ibrahim, M. K., dan Wahab, W. (2012). Determinants of Accounting for Investment Property (FRS 140) in Property Sector: Evidence from Malaysia. Prosiding. 3rd International Conference on Business and Economic Research: Bandung.

Jensen, M. C., dan Meckling, W. H. (1976). Theory of the firm: Managerial behavior, agency costs and ownership structure. Journal of Financial Economics, 3(4), 305-360.

Kadir, A. (2016). Analisis Pengaruh Penerapan IFRS Mengenai Investment Property Terhadap Pengakuan Laba Perusahaan (Studi Kasus Pada PT Astra International Tbk., PT Astra Otoparts Tbk., dan PT Astra Graphia Tbk. yang Terdaftar di BEI). Jurnal Ilmiah Bisnis Dan Keuangan, 2(2), 107-116.

Manurung, A. H. (2013). Teori Informasi Asimetris. Didapat dari http:// finansialbisnis.com/Data2/Riset/T
eori\%20Informasi\%20Asimetris.pdf, 12 Juli 2019, pukul 13.20 WIB.

Martani, D., Siregar, S. V., Wardani, R., Farahmita, A., dan Tanujaya, E. (2012). Akuntansi Keuangan Menengah Berbasis PSAK. Jakarta: Salemba Empat.

Muller, K. A., Riedl, E. J., dan Sellhorn, T. (2008). Causes And Consequences Of Choosing Historical Cost Versus Fair Value. Didapat dari https://caremendoza.nd.edu/assets/152281/riedlmrs0 3062008.pdf, 20 September 2019, pukul 17.38 WIB.

Pratiwi, M. W., dan Tahar, R. S. (2017). Analisis Pengaruh Tingkat Hutang, Ukuran Perusahaan, Informasi Asimetri, Selisih Keuntungan Nilai Wajar, Dan Kepemilikan Saham Terhadap Pemilihan Metode Nilai Wajar Pada Properti Investasi. Media Riset Akuntansi, 7(1), 101-119.

Quagli, A., dan Avallone, F. (2010). Fair Value or Cost Model? Drivers of Choice for IAS 40 in The Real Estate Industry. European Accounting Review, 19(3), 461-493.

Santioso, L., dan Chandra, E. (2012). Pengaruh Profitabilitas, Ukuran Perusahaan, Leverage, Umur Perusahaan, Dan Dewan Komisaris Independen dalam Pengungkapan Corporate Social Responsibility. Jurnal Bisnis dan Akuntansi, 14(1), 17-30.

Sasongko, H., dan Marhamah, D. (2018). Analisis Pengaruh Penerapan IFRS Mengenai Investment Property Terhadap Penyajian Laporan Keuangan (Studi Kasus Pada Perusahan Sektor Otomotif Yang Terdaftar Di BEI). Jurnal Ilmiah Manajemen dan Akuntansi Fakultas Ekonomi, 6(1), 84-89.

Setiyono, E., dan Amanah, L. (2016). Pengaruh Kinerja Keuangan dan Ukuran Perusahaan Terhadap Return Saham. Jurnal Ilmu dan Riset Akuntansi, 5(5), 1-17.

Taplin, R., Yuan, W., dan Brown, A. (2014). The Use of Fair Value and Historical Cost Accounting for Investment Properties In China. Australasian Accounting, Business and Finance Journal, 8(1), 101-113.

Umbara, D., Oemar, A., dan Pranaditya, A. (2017). Pengaruh Penerapan PSAK Konvergensi IFRS Terhadap Relevansi Nilai Informasi Akuntansi dengan DNI Sebagai Variabel Moderating Pada Perusahaan Manufaktur di BEI Periode 2007-2009 dan 2014-2016. Journal Of Accounting, 3(3), 1-18. 
Wiryadi, A., dan Sebrina, N. (2013). Pengaruh

Asimetri Informasi, Kualitas Audit, dan

Struktur Kepemilikan Terhadap

Manajemen Laba. Wahana Riset Akuntansi,

1(2), 155-180. 